\title{
Wealth Index, Education, Access to Electronic Media and Awareness about Tuberculosis: Pakistan Demographic and Health Survey 2012-13
}

\author{
Muhammad Zubair Tahir* \\ FANA Global Consultancy and Business Limited, UK.
}

\begin{abstract}
Objective: To investigate association of education, wealth index and access to electronic media with awareness about TB and its spread among women.

Material and Methods: Countrywide Pakistan Demographic and Health Survey (PDHS) 2012-13 data was selected for secondary analysis. From 12,943 occupied households, 13,558 ever-married women and 3,134 ever married men age 15-49 were interviewed. For this study, women interviews record was selected and analysed for TB awareness and its relationship with education attainment, wealth index and electronic media exposure.
\end{abstract}

SPSS logistic regression analyses were performed for statistical significance and to discover association between TB awareness and education attainment, wealth index and electronic media. A p-value of $<0.05$ was considered to be statistically significant.

Results: The poorest uneducated women had the lowest awareness about TB and its spread by air. Awareness about TB and its spread by coughing and sneezing increased with increase in education level and households' wealth and living standard.

Women from households having radio, in rural areas, had overall more awareness about TB and its spread by coughing and sneezing than women from households having no radio. Women of households having TV, in all regions of the country, had distinctly higher awareness about TB spread by air than women of households who had no TV.

Interestingly, there was more awareness among women of households having no radio and TV about TB spread by sharing utensils, touching person and sexual contact than women of households having radio and TV.

Education attainment and TV in households were more statistical significant than radio in households and wealth index. Education, wealth index and TV in households have relationship with TB spread by coughing and sneezing.

Conclusion: Awareness about tuberculosis and its spread by air among women was associated with increase in wealth, education level and exposure to electronic media. Use of electronic media would be helpful in creating awareness, in minimal time, about all aspects of tuberculosis.

Keywords: Education, Wealth Index, Electronic media, Tuberculosis, Awareness, Nervous system.

\section{INTRODUCTION}

Tuberculosis (TB) has re-emerged worldwide and is a serious health problem worldwide. It is caused by bacteria Mycobacterium tuberculosis and affecting human's health since ancient time. In 1882, German physician Robert Koch discovered Mycobacterium tuberculosis, cause of TB, and later its vaccine was introduced in 1921 [1]. A study of remains of 7000-year-old individuals, belonged to former Neolithic population, recovered from graves, pits, ditches, houses and other places at Hódmezővásárhely-Gorzsa in Hungary confirmed the presence of tuberculosis disease [2].

Tuberculosis is an air borne disease, spreads by cough and sneeze of infected persons. A healthy person cannot get TB from clothes, drinking glass, eating utensils, handshake,

*Address correspondence to this author at the FANA Global Consultancy and Business Limited 1 St Agatha's Road, Ward End B8 2TU, Birmingham

United Kingdom. E-mail: zubair01pk@yahoo.com sharing toilet and used other surfaces of a person having tuberculosis.

TB mainly affects the lungs, but it can affect any part of the body including the abdomen glands, bones and nervous system. TB is a serious condition which can lead to death but is curable and preventable. When a person having the disease coughs, sneezes or spits, the TB germs go into the air and infect others. A person needs to inhale only a few of these germs to become infected [3]. Lung is the most common site of its growth and immunity plays an important role in the development of TB [4].

World Health Organisation (WHO) estimated that about one-quarter of the world's population has latent TB. It means people have been infected by TB bacteria (Mycobacterium Tuberculosis) but did not get illness, cannot transmit the disease and have a $5-15 \%$ lifetime risk of getting TB. It was also estimated that in 2016, there were 1.7 million deaths due 
to TB worldwide [5]. Ending the TB epidemic by 2030 is one of the health targets of the sustainable development goals of WHO [6].

According to 2016, estimated statistics of TB in high burden countries, Pakistan TB incidence was estimated 518000 and there were 44000 TB related mortalities [7]. In Pakistan, the incidence of tuberculosis from 2003 to 2012 remained 276 (per 100,000 people), and in 2015 it reduced to 270 (per 100,000 people) [8].

According to National TB Control Programme (NTP) in Pakistan, about 420,000 persons in the country get TB disease annually and the country ranked 5 th among those countries that have the highest burden of TB disease globally. NTP is making efforts for making TB free Pakistan by reducing 50\% prevalence of TB in the population by 2025 but TB cases are increasing [9].

In WHO Eastern Mediterranean Regional (EMRO) countries, the incidence of tuberculosis (per 100,000 people) in 2016 varied. It was 268 in Pakistan, Bahrain reported 12, Egypt had 14, Iran showed 14, Iraq stated 43, South Sudan declared 146, Saudi Arabia revealed 10, Tunisia affirmed 34 and 270 was in Somalia [8].

Mycobacterium tuberculosis has gradually become deadlier organism due to drug resistance. TB treatment is of long duration, sometimes more than two years, and is also associated with side effects so TB patients often do not complete the full course of drug therapy. Long and incomplete TB treatment has been resulting in single and multi-drug resistant TB (MDR-TB) strains [1]. Globally, Pakistan has 4th place among multi drug resistant TB countries [9]. A study revealed that TB reporting in Pakistan was under-reported [10].

TB is one of the top five killers of adult women aged 20-59 years. TB mainly affects women and its impact is also strongly felt by their children and families. TB among mothers is related with a six-fold increase in perinatal deaths [11]. Awareness about TB, its ways of spread, knowledge about effects of getting late and incomplete TB treatment are related with early detection of the disease, lower risk of its spread, complete proper TB treatment and follow ups.

Although free treatment for TB is available in Pakistan, but unfortunately late detection and high rate of unsuccessful TB treatments has been observed. This shows that, in Pakistan, there is lack of awareness about TB, its spread, control and dearth of knowledge about consequences of late and incomplete TB treatment. The important factors, related to these, include education level, wealth in family and awareness through mass media.

Along with other thing, there are gaps in communication, so people are unaware about TB, control and its spread. There is strong relationship between various sources of information and higher awareness about TB risks [12]. Access to media can play an important role in education about TB in short time [13].

In Pakistan, majority people live in joint family system and women not only look after their children but other family members also. They have pivot role and their education about the disease has prime importance, so study was focussed to find their awareness about TB.

Main objective is to investigate association of education, wealth index and access to electronic media with awareness about TB and its spread among women.

\section{MATERIAL AND METHODS}

Pakistan Demographic and Health Survey (PDHS) 2012-13 was conducted by Pakistan's Ministry of Planning and Development. Except restricted military protected areas, Azad Jammu \& Kashmir (AJK) and Federally Administered Tribal Area (FATA), the survey was conducted from October 2012 to April 2013 in all areas of Pakistan.

For the survey 14,000 households from all regions, 6,944 in urban areas and 7,056 in rural areas were selected. From 12,943 occupied households, 13,558 ever-married women and 3,134 ever married men age 15-49 were interviewed. For this study, only women responses were selected and analysed.

\section{Analysis of Data}

IBM Software Package for Social Sciences (SPSS) version 21 (IBM, NY, USA) was used to analyse the data. The association between dependent and independent selected variables was assessed by SPSS logistic regression analyses. A p-value of $<0.05$ was considered statistically significant.

\section{Dependant Variables}

Tuberculosis awareness categories were:

(1) Heard of tuberculosis or TB (2) Tuberculosis spread by: air through coughing or sneezing (3) Tuberculosis spread by sharing utensils (4) Tuberculosis spread by touching a person with TB (5) Tuberculosis spread by sexual contact.

There were two alternatives to all answers (1) No and (2) Yes.

\section{Independent Variables}

\section{Electronic Media Exposure}

There were two categories for exposure to electronic media (1) Household has radio and (2) Household has TV. There were two answers only (1) No (2) Yes

\section{Education Attainment}

Highest education level was categorised into: (1) No education (2) Primary (3) Secondary (4) Higher. 
No education means no school education. Primary means school classes from1-5, Secondary is school classes from 9-10 and Higher demonstrates classes from 11-16. Every class means study year in school/college/university.

\section{Wealth Index}

Information on household assets was used to create a wealth index. There were five categories created based on these household economic indicators; (1) Poorest (2) Poorer (3) Middle (4) Richer and (5) Richest.

\section{RESULTS}

Education and Wealth Index Association with TB Awareness

Table 1 is about impact of education and wealth index on awareness about TB and its spread. It shows that women having no education and the poorest had the lowest awareness about TB and its spread by coughing and sneezing. With increase in education and wealth, awareness about TB and its spread by air increased.

The poorest women who had also no education had overall more awareness about TB spread by touching person, sharing utensils and sexual contact than women who had school education and were in upper wealth index categories.

Table 1. Education, Wealth Index and TB Awareness among Women.

\begin{tabular}{|c|c|c|c|c|c|c|c|c|c|}
\hline \multirow{2}{*}{$\begin{array}{c}\text { TB Awareness } \\
\text { Questions }\end{array}$} & \multicolumn{7}{|c|}{ Education Attainment } & \multicolumn{3}{c|}{ Wesponses in \% (n=13543) } \\
\cline { 2 - 10 } & Education & Primary & Secondary & Higher & Poorest & Poorer & Middle & \multicolumn{1}{c|}{ Richer } & Richest \\
\hline Heard of TB & 88.8 & 95.4 & 97.4 & 99.6 & 83.5 & 90.2 & 93.6 & 95.3 & 98.5 \\
\hline $\begin{array}{c}\text { TB spreads } \\
\text { by air: } \\
\text { coughing \& } \\
\text { sneezing }\end{array}$ & 40.0 & 50.0 & 62.2 & 79.6 & 30.8 & 41.2 & 49.4 & 55.9 & 68.5 \\
\hline $\begin{array}{c}\text { TB spreads by } \\
\text { sharing } \\
\text { utensils }\end{array}$ & 38.6 & 42.5 & 44.5 & 49.8 & 34.3 & 40.4 & 44.0 & 42.7 & 45.1 \\
\hline $\begin{array}{c}\text { TB spreads by } \\
\text { touching } \\
\text { person }\end{array}$ & 11.0 & 10.3 & 13.0 & 15.6 & 10.3 & 11.3 & 11.5 & 13.0 & 12.8 \\
\hline $\begin{array}{c}\text { TB spreads by } \\
\text { sexual contact }\end{array}$ & 8.4 & 10.0 & 10.5 & 11.8 & 6.5 & 10.2 & 11.2 & 9.7 & 9.3 \\
\hline
\end{tabular}

Pakistan Demographic and Health Survey 2012-13.

\section{Awareness about TB Related to Electronic Media Exposure}

Table 2 shows comparison of TB awareness and its spread among women of households having radio and TV with women of households having no radio and TV. It shows that in rural areas, women from households having radio had overall more awareness about TB and its spread by coughing and sneezing than women of households without radio. Generally, women from households without radio were more aware about TB spread by other means than women of households having radio.

In all parts of the country, women of households having TV had markedly higher awareness of TB spread by coughing and sneezing than women of households who had no TV. Regarding awareness about sharing utensils, touching person and sexual contact of TB spread, women of households having no TV had more awareness than women of households having TV. 
Table 2. TB Awareness among Women, Exposed to Electronic Media (Radio and TV).

\begin{tabular}{|c|c|c|c|c|c|c|c|c|c|c|c|}
\hline \multirow{3}{*}{$\begin{array}{l}\text { TB Awareness } \\
\text { Questions }\end{array}$} & \multirow{3}{*}{$\begin{array}{l}\text { House-Holds } \\
\text { have Radio }\end{array}$} & \multicolumn{10}{|c|}{ Regions and YES Responses of Women in \% $(n=11,731)$} \\
\hline & & \multirow[t]{2}{*}{ Islamabad } & \multicolumn{2}{|c|}{ Punjab } & \multicolumn{2}{|c|}{ Sind } & \multicolumn{2}{|c|}{\begin{tabular}{|c|} 
Khyber \\
Pakhtunkhwa
\end{tabular}} & \multicolumn{2}{|c|}{ Balochistan } & \multirow[t]{2}{*}{$\begin{array}{c}\text { Gilgit } \\
\text { Baltistan }\end{array}$} \\
\hline & & & Urban & Rural & Urban & Rural & Urban & Rural & Urban & Rural & \\
\hline Heard of TB & $\begin{array}{l}\text { No } \\
\text { Yes }\end{array}$ & $\begin{array}{l}97.0 \\
99.3\end{array}$ & $\begin{array}{l}96.5 \\
96.5\end{array}$ & $\begin{array}{l}94.7 \\
99.2\end{array}$ & $\begin{array}{l}97.8 \\
100\end{array}$ & $\begin{array}{l}97.3 \\
100\end{array}$ & $\begin{array}{l}93.4 \\
97.0\end{array}$ & $\begin{array}{l}91.4 \\
89.3\end{array}$ & $\begin{array}{l}88.2 \\
85.8\end{array}$ & $\begin{array}{l}77.1 \\
79.0\end{array}$ & $\begin{array}{l}74.8 \\
72.0\end{array}$ \\
\hline $\begin{array}{l}\text { TB spreads by air: } \\
\text { coughing } \& \text { sneezing }\end{array}$ & $\begin{array}{l}\text { No } \\
\text { Yes }\end{array}$ & $\begin{array}{l}68.1 \\
70.5\end{array}$ & $\begin{array}{l}57.0 \\
50.4\end{array}$ & $\begin{array}{l}42.3 \\
49.2\end{array}$ & $\begin{array}{l}53.7 \\
42.2\end{array}$ & $\begin{array}{l}28.9 \\
28.3\end{array}$ & $\begin{array}{l}51.4 \\
65.9\end{array}$ & $\begin{array}{l}44.0 \\
41.1\end{array}$ & $\begin{array}{l}61.4 \\
62.7\end{array}$ & $\begin{array}{l}35.8 \\
53.5\end{array}$ & $\begin{array}{l}44.6 \\
39.7\end{array}$ \\
\hline $\begin{array}{c}\text { TB spreads by sharing } \\
\text { utensils }\end{array}$ & $\begin{array}{l}\text { No } \\
\text { Yes }\end{array}$ & $\begin{array}{l}41.7 \\
36.0\end{array}$ & $\begin{array}{l}48.7 \\
42.5\end{array}$ & $\begin{array}{l}46.7 \\
51.6\end{array}$ & $\begin{array}{l}33.7 \\
45.6\end{array}$ & $\begin{array}{l}40.3 \\
57.2\end{array}$ & $\begin{array}{l}42.8 \\
47.6\end{array}$ & $\begin{array}{l}45.4 \\
42.0\end{array}$ & $\begin{array}{l}38.1 \\
30.0\end{array}$ & $\begin{array}{l}26.4 \\
29.1\end{array}$ & $\begin{array}{l}24.8 \\
23.9\end{array}$ \\
\hline $\begin{array}{l}\text { TB spreads by } \\
\text { touching person }\end{array}$ & $\begin{array}{l}\text { No } \\
\text { Yes }\end{array}$ & $\begin{array}{l}10.9 \\
7.2\end{array}$ & $\begin{array}{l}8.9 \\
9.7\end{array}$ & $\begin{array}{c}9.7 \\
19.0\end{array}$ & $\begin{array}{l}12.7 \\
14.4\end{array}$ & $\begin{array}{l}10.5 \\
7.6\end{array}$ & $\begin{array}{l}9.3 \\
7.9\end{array}$ & $\begin{array}{l}11.7 \\
17.4\end{array}$ & $\begin{array}{l}18.3 \\
14.2\end{array}$ & $\begin{array}{l}16.5 \\
15.7\end{array}$ & $\begin{array}{l}8.7 \\
9.2\end{array}$ \\
\hline $\begin{array}{l}\text { TB spreads by sexual } \\
\text { contact }\end{array}$ & $\begin{array}{l}\text { No } \\
\text { Yes }\end{array}$ & $\begin{array}{l}8.1 \\
7.2\end{array}$ & $\begin{array}{c}7.2 \\
12.4 \\
\end{array}$ & $\begin{array}{l}11.1 \\
11.1\end{array}$ & $\begin{array}{l}6.5 \\
2.2\end{array}$ & $\begin{array}{l}5.4 \\
4.1 \\
\end{array}$ & $\begin{array}{l}8.8 \\
6.7\end{array}$ & $\begin{array}{c}8.4 \\
12.1 \\
\end{array}$ & $\begin{array}{l}13.9 \\
15.8\end{array}$ & $\begin{array}{l}10.6 \\
15.1\end{array}$ & $\begin{array}{l}3.2 \\
1.9\end{array}$ \\
\hline $\begin{array}{l}\text { TB Awareness } \\
\text { Questions }\end{array}$ & $\begin{array}{c}\text { House-Holds } \\
\text { have TV }\end{array}$ & \multicolumn{10}{|c|}{$(n=11736)$} \\
\hline Heard of TB & $\begin{array}{l}\text { No } \\
\text { Yes }\end{array}$ & $\begin{array}{l}98.2 \\
97.3\end{array}$ & $\begin{array}{l}95.5 \\
96.7\end{array}$ & $\begin{array}{l}92.8 \\
96.8\end{array}$ & $\begin{array}{l}94.4 \\
98.6\end{array}$ & $\begin{array}{l}96.5 \\
99.4\end{array}$ & $\begin{array}{l}92.9 \\
94.8\end{array}$ & $\begin{array}{l}89.5 \\
94.1\end{array}$ & $\begin{array}{l}63.5 \\
93.2\end{array}$ & $\begin{array}{l}71.7 \\
87.3\end{array}$ & $\begin{array}{l}71.7 \\
87.3\end{array}$ \\
\hline $\begin{array}{l}\text { TB spreads by air: } \\
\text { coughing \& sneezing }\end{array}$ & $\begin{array}{l}\text { No } \\
\text { Yes }\end{array}$ & $\begin{array}{l}48.2 \\
72.5\end{array}$ & $\begin{array}{l}45.8 \\
57.9\end{array}$ & $\begin{array}{l}37.5 \\
47.1\end{array}$ & $\begin{array}{l}26.1 \\
57.2\end{array}$ & $\begin{array}{l}24.7 \\
35.8\end{array}$ & $\begin{array}{l}48.0 \\
57.9\end{array}$ & $\begin{array}{l}35.2 \\
59.4\end{array}$ & $\begin{array}{l}36.5 \\
68.3\end{array}$ & $\begin{array}{l}30.5 \\
57.6\end{array}$ & $\begin{array}{l}30.5 \\
57.6\end{array}$ \\
\hline $\begin{array}{c}\text { TB spreads by sharing } \\
\text { utensils }\end{array}$ & $\begin{array}{l}\text { No } \\
\text { Yes }\end{array}$ & $\begin{array}{l}34.5 \\
41.7\end{array}$ & $\begin{array}{l}46.5 \\
48.2\end{array}$ & $\begin{array}{l}48.6 \\
45.7\end{array}$ & $\begin{array}{l}36.6 \\
34.4\end{array}$ & $\begin{array}{l}39.2 \\
47.1\end{array}$ & $\begin{array}{l}46.9 \\
42.3\end{array}$ & $\begin{array}{l}45.2 \\
44.3\end{array}$ & $\begin{array}{l}19.2 \\
39.1\end{array}$ & $\begin{array}{l}22.3 \\
34.8\end{array}$ & $\begin{array}{l}22.3 \\
34.8\end{array}$ \\
\hline $\begin{array}{l}\text { TB spreads by } \\
\text { touching person }\end{array}$ & $\begin{array}{l}\text { No } \\
\text { Yes }\end{array}$ & $\begin{array}{l}13.6 \\
9.4\end{array}$ & $\begin{array}{l}4.5 \\
9.7\end{array}$ & $\begin{array}{c}9.6 \\
10.9\end{array}$ & $\begin{array}{l}13.0 \\
12.8\end{array}$ & $\begin{array}{c}8.1 \\
13.5\end{array}$ & $\begin{array}{l}8.3 \\
9.4\end{array}$ & $\begin{array}{l}11.0 \\
15.5\end{array}$ & $\begin{array}{l}9.6 \\
18.5\end{array}$ & $\begin{array}{l}15.9 \\
17.3\end{array}$ & $\begin{array}{l}15.9 \\
17.3\end{array}$ \\
\hline $\begin{array}{l}\text { TB spreads by sexual } \\
\text { contact }\end{array}$ & $\begin{array}{l}\text { No } \\
\text { Yes }\end{array}$ & $\begin{array}{l}11.8 \\
7.1\end{array}$ & $\begin{array}{l}6.5 \\
8.0\end{array}$ & $\begin{array}{l}10.8 \\
11.3\end{array}$ & $\begin{array}{l}6.2 \\
6.2\end{array}$ & $\begin{array}{l}3.9 \\
7.5\end{array}$ & $\begin{array}{l}11.0 \\
7.0\end{array}$ & $\begin{array}{c}7.6 \\
11.6\end{array}$ & $\begin{array}{c}7.2 \\
16.3\end{array}$ & $\begin{array}{l}11.8 \\
11.9\end{array}$ & $\begin{array}{l}11.8 \\
11.9\end{array}$ \\
\hline
\end{tabular}

Pakistan Demographic and Health Survey 2012-13.

\section{Statistical Significance and Association of Variables}

Table $\mathbf{3}$ is about statistical significance and association of TB awareness with electronic media exposure, education and wealth index. Statistical analyses were done by SPSS multinomial logistic regression model. Results of likelihood ratio tests show that education attainment and TV in households are more statistical significant than wealth index and radio in households. Education, wealth index and TV in households have associations with TB spread by coughing and sneezing.

Table 3. Statistical Significance and Association Between Awareness about TB among Women (DVs) and Education Attainment, Wealth Index and Electronic Media (IVs).

\begin{tabular}{|c|c|c|c|c|c|c|c|c|}
\hline \multirow{2}{*}{$\begin{array}{c}\text { Questions about } \\
\text { TB Awareness }\end{array}$} & \multicolumn{2}{|c|}{ Education Attainment } & \multicolumn{2}{|c|}{ Wealth Index } & Radio in Households & \multicolumn{2}{c|}{ TV in Households } \\
\cline { 2 - 10 } & Chi-Square & $\mathrm{p}$ value & Chi-Square & $\mathrm{p}$ value & Chi-Square & $\mathrm{p}$ value & Chi-Square & $\mathrm{p}$ value \\
\hline Heard of TB & 139.882 & $<0.001$ & 173.966 & $<0.001$ & 59.194 & 0.001 & 313.648 & 0.001 \\
\hline $\begin{array}{c}\text { TB spreads by air: } \\
\text { coughing \& sneezing }\end{array}$ & 378.106 & $<0.001$ & 250.270 & $<0.001$ & 0.790 & 0.374 & 571.569 & 0.001 \\
\hline $\begin{array}{c}\text { TB spreads by sharing } \\
\text { utensils }\end{array}$ & 40.278 & $<0.001$ & 36.979 & $<0.001$ & 10.912 & 0.001 & 28.301 & 0.001 \\
\hline $\begin{array}{c}\text { TB spreads by } \\
\text { touching person }\end{array}$ & 25.152 & $<0.001$ & 5.284 & 0.259 & 1.026 & 0.311 & 14.956 & 0.001 \\
\hline $\begin{array}{c}\text { TB spreads by sexual } \\
\text { contact }\end{array}$ & 25.734 & $<0.001$ & 40.381 & $<0.001$ & 1.402 & 0.236 & 7.727 & 0.005 \\
\hline
\end{tabular}

(SPSS Multinomial Logistic Regression Analysis, likelihood ratio tests results). 


\section{DISCUSSION}

This study shows that rise in education level and wealth improved awareness about TB and its spread by coughing and sneezing. The poorest women having no education had the lowest awareness of TB spread by air but had more awareness about TB spread by other means than women having education and from upper categories of wealth index. Women from households having radio in rural areas had overall more awareness about TB and its spread by coughing and sneezing than women of households without radio. TV in households and education attainment have more statistical significance than wealth index and radio in households. Wealth index, TV in households and education are related with awareness of TB spread by air.

This study focussed on women awareness about TB and its spread. In Pakistan, most women spend maximum time of day with their children and other family members, so their awareness about the disease is important. People having active TB are more likely to spread it to people living close to them. There is need to educate that TB is not transferred by shaking hand, sharing drink or food, touching bed sheets or toilet seats, sharing toothbrushes and kissing [14].

This study shows that the poorest women had the least TB awareness about TB and its spread by air. It means that lack of awareness does not develop the disease but can spread the disease. A study of national surveys of eight countries revealed that there is no clear and firm association between household socio-economic level and individual TB disease [15]. Due to lack of TB awareness, its transmission to others is more common in poor communities than in rich communities [16].

This study shows that increase in level of education is related with enhancement of TB awareness. A study showed similar results and concluded that level of education was considerably related with TB awareness [17].

Our study shows that women without education had the lowest awareness about TB. In rural areas, majority of girls have no opportunity to get school education. According to UNICEF, only 20 per cent of girls from rural households are in school, while 81 per cent girls go to school from urban households [18]. The interesting finding of this study is that women without school education had more awareness about TB spread by sharing utensils, sexual contact and touching person than women who were educated.

This study shows that radio in rural areas has its role in creating TB awareness. About $60 \%$ people in Pakistan live in rural areas and mostly listen radio. A study shows that people who had access to radio were more well-informed on tuberculosis transmission compared to those persons who had no access to radio [19].
Our study discovered that women having TV exposure had considerably higher awareness of TB spread by coughing and sneezing than women who had no TV exposure. A study shows that TV significantly improved knowledge about TB among people [20]. Radio is listened mainly in rural areas and $\mathrm{TV}$ in all parts of the country. Radio and television are the most effective sources of information on TB, its spread, diagnosis and treatment [21].

Multidrug-resistant tuberculosis (MDR-TB) patients are increasing in Pakistan. The important risk factor for MDR-TB is previous incomplete treatment for TB [22]. A study in Pakistan found that low educational status and poverty are directly related to non-compliance and denial of TB treatment [23].

The increased in tuberculosis cases in Pakistan are due to lack of awareness about signs, symptoms, spread and treatment [24]. Under-detection and delay in treatment of $\mathrm{TB}$ in Pakistan is also related to lack of awareness about its signs and symptoms [25].

National TB Control programme of Pakistan staff is working hard for TB free Pakistan and reduce fifty per cent TB prevalence by 2025 [26]. Electronic media can be helpful for achieving the targets in short time. Study in Karachi revealed that college and university students had deficient knowledge about TB [27]. In Pakistan, for the last few years, about more than 80 TV channels have been launched. They can be helpful for TB awareness. Media campaigns should include accurate and complete information about the disease [21].

In a study in Punjab, high death rate was found among patients who got drug resistant tuberculosis treatment [28]. A study in Sind showed that people living in rural areas had no proper knowledge of tuberculosis, its spread and treatment [29]. Television and radio can be used for creating awareness and changing health related behaviours [30]. A study revealed that $94 \%$ participants rated the video as highly acceptable, informative and their knowledge about tuberculosis improved after viewing the video [31].

The electronic media influence has grown significantly with passage of time. We live in a society that depends on information and communication for our daily activities. The beliefs and values now based on what we have information/know. However, the influence of electronic mass media has touched every sphere of the human aspect.

In Pakistan rural areas, educational institutions are lesser than urban areas while about sixty per cent people are living there. Economic activity has decreased leading poverty. Women have been badly affected and are prone of getting and spreading TB. It will take very long time to increase education levels and enhance socioeconomic status of population. 
Increase in TB prevalence, MDR-TB and TB related deaths are real challenges. In minimum time, electronic media, radio and TV, can play an important role in creating awareness about TB, its spread, treatment benefits and MDR-TB.

PDHS 2012-13 has significantly higher women interviews than men which are very helpful in assessments about their knowledge and attitudes for other health issues and TB also. In the survey, in questionnaire, questions about TB awareness sources were not included. The data from such questions could be helpful to assess, in better way, education, socioeconomic status and electronic media impact on awareness about TB.

\section{CONCLUSION}

Awareness about tuberculosis and its spread by air among women was associated with increase in wealth, education level and exposure to electronic media. Use of electronic media would be helpful in creating awareness, in minimal time, about all aspects of tuberculosis.

\section{CONFLICT OF INTEREST}

Declared none.

\section{ACKNOWLEDGEMENTS}

I am grateful to Pakistan Demographic and Health Survey (PDHS) organising committee for support, cooperation and permission to download PDHS 2012-13 data for the study.

\section{REFERENCES}

[1] National Institutes of Health. Tuberculosis. Available at: https://www.report.nih.gov/NIHfactsheets/ViewFactSheet.aspx?csid=31 [Accessed 01 February 2018].

[2] Masson M, Bereczki Z, Molnar E, et al. 7000 year-old tuberculosis cases from Hungary - Osteological and biomolecular evidence. Tuberculosis (Edinb) 2015; (95 Suppl 1): S13-7. DOI: $10.1016 /$ j.tube.2015.02.007

[3] Nicas M, Nazaroff WW, Hubbard A. Towards understanding the risk of secondary airborne infection: Emission of respirable pathogens. J Occup Environ Hyg 2005; 2(5): 143-54.

DOI: $10.1080 / 15459620590918466$

[4] Centers for Disease Control and Prevention. Tuberculosis (TB). Available at: https://www.cdc.gov/tb/topic/basics/exposed.htm [Accessed 02 February 2018].

[5] World Health Organisation. Tuberculosis (TB). Key facts. Available at: http://www.who.int/en/news-room/fact-sheets/detail/tuberculosis [Assessed 12 September 2018].

[6] World Health Organisation. Media centre. Tuberculosis. Available at: http://www.who.int/mediacentre/factsheets/fs104/en/ [Assessed 21 March 2018].

[7] TBFACTS. TB Statistics -Global, deaths, regional, age \& high burden. Available at: https://www.tbfacts.org/tb-statistics/ [Accessed 01 April 2018].

[8] The World Bank. Data. Incidence of tuberculosis (per 1000 people). Available at: https://data.worldbank.org/indicator $/$ SH.TBS.INCD? end $=2015$ \&locations $=$ PK\&start $=2000$ [Accessed 01 April 2018].

[9] NTP. Tuberculosis Control in Pakistan. Available at: http://ntp.gov.pk/uploads/ntp_1369817904_CURRICULUM_FOR_MBBS_STUDENTS.pdf [Accessed 25 March 2018].

[10] Fatima R, Harris RJ, Enarson DA, et al. Estimating tuberculosis burden and case detection in Pakistan. Int J Tuberc Lung Dis 2014; 18(1): 55-60. DOI: 10.5588/ijtld.13.0198

[11] World Health Organization. Tuberculosis in women. Available at: http://www.who.int/tb/publications/tb_women_factsheet_251013.pdf [Accessed 04 May 2018].

[12] Chizimba R, Christofides N, Chirwa T, et al. The association between multiple sources of information and risk perceptions of tuberculosis, Ntcheu district, Malawi. PLoS One 2015;10(4): e0122998. DOI: 10.1371/journal.pone.0122998

[13] Khandoker A, Khan MM, Krämer A, Mori M. Knowledge about tuberculosis transmission among ever-married women in Bangladesh. Int J Tuberc Lung Dis 2011; 15(3): 379-84.

[14] Centers for Disease Control and Prevention. How TB Spreads. Available at: https://www.cdc.gov/tb/topic/basics/howtbspreads.htm [Accessed 10 June 2018].

[15] Siroka A, Law I, Macinko J, et al. The effect of household poverty on tuberculosis. Int J Tuberc Lung Dis 2016; 20(12): 1603-8. DOI: $10.5588 /$ ijtld.16.0386

[16] Bhunu CP, Mushayabasa S, Smith RJ. Assessing the effects of poverty in tuberculosis transmission dynamics. Appl Mathe Model 2012; 9(36): 4173-85.

[17] Suleiman MM, Sahal N, Sodemann M, Elsony A, Aro AR. Tuberculosis awareness in Gezira, Sudan: Knowledge, attitude and practice case-control survey. East Mediterr Health J 2014; 20(2): 120-9. DOI: 10.26719/2014.20.2.120

[18] UNICEF. Pakistan. Our work. Available at: https://www.unicef.org/pakistan/overview.html [Accessed 10 June $2018]$.

[19] Ismail A, Josephat P. Knowledge and perception on tuberculosis transmission in Tanzania: Multinomial logistic regression analysis of secondary data. Tanzan J Health Res 2014; 16 (1): 29-37. DOI: $10.4314 /$ thrb.v16i1.5

[20] Lee B, Oh HJ, Chon BS. Estimating the impact of a television campaign on tuberculosis knowledge and intention to test for TB in South Korea. Int J Tuberc Lung Dis 2018; 22(1): 60-4. DOI: $10.5588 /$ ijtld.17.0203 
[21] Naidoo P, Simbayi L, Labadarios D, et al. Predictors of knowledge about tuberculosis: Results from SANHANES I, a national, cross-sectional household survey in South Africa. BMC Public Health 2016; 16: 276.

DOI: $10.1186 / \mathrm{s} 12889-016-2951-y$

[22] Kidenya BR, Webster LE, Behan S, et al. Epidemiology and genetic diversity of multidrug-resistant tuberculosis in East Africa. Tuberculosis (Edinb) 2014; 94(1): 1-7.

DOI: $10.1016 /$ j.tube.2013.08.009

[23] Khan AU, Akhtar N, Madni A, et al. Socio-economic constrains faced by TB patients that lead to non-compliance A cross sectional study in southern Punjab, Pakistan. Acta Pol Pharm 2017; 74(3): 995-1000.

[24] Kamal M, Ali S, Hussain SJ, Abbasi MA. Demographics of tuberculosis in district Mansehra. J Ayub Med Coll Abbottabad 2015; 27(4): 890-3.

[25] Qadeer E, Fatima R, Yaqoob A, et al. Population based national tuberculosis prevalence survey among Adults ( $>15$ Years) in Pakistan, 2010-2011. PLoS One 2016; 11(2): e0148293. DOI: 10.1371/journal.pone.0148293

[26] NTP. National TB Control Programme of Pakistan. Available at: http://www.ntp.gov.pk/cmsPage.php?pageID=7 [Accessed
02 April 2018].

[27] Khalid N, Khan A, Ali H, et al. Knowledge, attitude and practice regarding pulmonary tuberculosis awareness among non-medical students of Karachi. J Bahria Uni Med Dental Coll 2015; 5(1): 37-40.

[28] Kanwal S, Akhtar AM, Ahmed A. Factors associated with mortality to drug-resistant tuberculosis and their programmatic management in treatment centres of Punjab, Pakistan. J Pak Med Assoc 2017; 67(6): 858-62.

[29] Ali Warsi SM, Danish SH, Ahmad F, et al. Tuberculosis knowledge and health seeking behaviour: A tale of two districts of Sindh, Pakistan. J Pak Med Assoc 2016; 66(9): 1120-6.

[30] Ali Z, Janand M, Bukhari SQ. Role of electronic media in changing value system in Pakistan. Int Asian Res J 2013: 1(1): 59-65.

[31] Wieland ML, Nelson J, Palmer T, et al. Evaluation of a tuberculosis education video among immigrants and refugees at an adult education center: A community-based participatory approach. J Health Commun 2013;18 (3): 343-53. DOI: $10.1080 / 10810730.2012 .727952$

(C) 2018 National Journal of Health Sciences.

This is an open-access article. 